\title{
Small Preterm Infants ( $\leq 1500$ g) Have Only a Sustained Decrease in Ventilation in Response to Hypoxia ${ }^{1}$
}

\author{
RUBEN ALVARO, JORGE ALVAREZ, KIM KWIATKOWSKI, DONALD CATES, AND \\ HENRIQUE RIGATTO \\ Departments of Pediatrics, Physiology, and Reproductive Medicine, University of Manitoba. \\ Winnipeg, Manitoba, Canada
}

\begin{abstract}
The classic "biphasic" ventilatory response to $15 \% \mathrm{O}_{2}$ was previously observed in preterm infants who were large compared with those in the intensive care nursery today. We hypothesized that in the smaller infant $(\leq 1500 \mathrm{~g})$ the response might be closer to that of the fetus, with no initial increase in ventilation. Thus, we studied 14 healthy preterm infants $\leq 1500 \mathrm{~g}$ [birth weight $1220 \pm 63$ $\mathrm{g}$ (mean $\pm \mathrm{SEM}$ ); gestational age $29 \pm 0.4 \mathrm{wk}$; postnatal age $17 \pm 3 \mathrm{~d}$ ] during rapid eye movement and quiet sleep. Ventilation was measured using a nosepiece and a flowthrough system. Sleep states were defined using EEG, electro-oculogram, and body movements. After a control period in $21 \% \mathrm{O}_{2}$ (3 min), infants breathed $15 \% \mathrm{O}_{2}$ for 5 min. In rapid eye movement sleep, minute ventilation decreased from $0.186 \pm 0.020$ (control) to $0.178 \pm 0.021$ (30 s), to $0.171 \pm 0.017$ ( $1 \mathrm{~min} ; p=0.03)$, to $0.145 \pm 0.016$ (3 $\mathrm{min} ; p=0.002)$, and to $0.129 \pm 0.011 \mathrm{1} \cdot \mathrm{min}^{-1} \cdot \mathrm{kg}^{-1}(5$ $\min ; p=0.004)$. In quiet sleep, it decreased from $0.173 \pm$ 0.019 (control) to $0.164 \pm 0.019$ (30 s), to $0.166 \pm 0.019$ (1 min), to $0.148 \pm 0.013(3 \mathrm{~min} ; p=0.03)$, and to 0.146 $\pm 0.0121 \cdot \mathrm{min}^{-1} \cdot \mathrm{kg}^{-1}(5 \mathrm{~min} ; p=0.04)$. These changes in ventilation were primarily related to a decrease in frequency in rapid eye movement $[38 \pm 2$ (control) versus 28 $\pm 3(5 \mathrm{~min}) ; p=0.01]$ and in quiet sleep [36 \pm 5 (control) versus $27 \pm 3(5 \mathrm{~min}) ; p=0.02$ ]. Changes in tidal volume were negligible. These findings suggest that the classic biphasic response to hypoxia is not observed in very small preterm infants. These infants show only a sustained decrease in ventilation with low $\mathrm{O}_{2}$. We speculate that the response reflects a more pronounced inhibitory mechanism induced by hypoxia at this gestational age, representing an intermediate profile between that observed in the fetus and that present in larger neonates. (Pediatr Res 32: 403-406, 1992)
\end{abstract}

\section{Abbreviations}

REM, rapid eye movement

$\mathbf{P}_{\mathbf{A}} \mathrm{O}_{2}$, alveolar $\mathbf{P O}_{2}$

$\mathbf{P}_{\mathrm{A}} \mathrm{CO}_{2}$, alveolar $\mathrm{PCO}_{2}$

Preterm infants have long been known to present a classic "biphasic" ventilatory response to $15 \% \mathrm{O}_{2}$ with an immediate

Received February 3, 1992; accepted May 27, 1992.

Correspondence and reprint requests: Dr. Henrique Rigatto, Professor of Pediatrics, Director, Neonatal Research, WR-125 - Women's Hospital, 735 Notre Dame Ave., Winnipeg. Manitoba, Canada R3E OL8.

Supported by the Medical Research Council of Canada, Grant MT-4980, and the Manitoba Health Research Council.

'Presented in part at the meeting of the Society for Pediatric Research, AprilMay 1991, New Orleans, LA.
( $30 \mathrm{~s})$ increase followed by a late $(5 \mathrm{~min})$ decrease in ventilation. The immediate increase in ventilation has been traditionally accepted as a reflection of peripheral chemoreceptor activity. The late response, however, is poorly understood and has been attributed to such factors as central hypoxic depression, decreased metabolic rate, and decreased compliance of the lungs (1-6). However, the infants who have shown this response have been larger and more mature than those admitted to the nursery today. We thought that in smaller and less mature infants $(\leq 1500$ g) the response to low inspired $\mathrm{O}_{2}$ may differ from that previously described. It might represent an intermediate response between the biphasic profile in larger preterm infants and the abrupt cessation of breathing in the fetus $(7,8)$.

We therefore designed this study to examine the ventilatory response to $15 \%$ inhaled $\mathrm{O}_{2}$ in preterm infants $\leq 1500 \mathrm{~g}$ to test the hypothesis that these infants show only a sustained decrease in ventilation in response to hypoxia.

\section{MATERIALS AND METHODS}

Subjects. We studied 14 healthy preterm infants $\leq 1500 \mathrm{~g}$. Birth weight was $1220 \pm 63 \mathrm{~g}$ (mean \pm SEM; range 785 to 1460 g), gestational age $29 \pm 0.4 \mathrm{wk}$, postnatal age $17 \pm 3 \mathrm{~d}$, and study weight $1250 \pm 78 \mathrm{~g}$. The study was approved by the Faculty Committee for the Use of Human Subjects in Research, University of Manitoba, and written consent was obtained from at least one parent of each infant.

Methods. The system used to measure ventilation and alveolar gases has been described in detail previously (9-11). Briefly, we used a nosepiece and a screen flowmeter to measure respiratory minute volume and alveolar gases. We eliminated valves and reduced dead space by using a constant background flow $(3 \mathrm{~L}$. $\mathrm{min}^{-1}$ ) which was electrically balanced to an artificial zero. The infant breathed through the nostril adapters and added to (expiration) or subtracted flow from (inspiration) the background flow. The flow signal was electrically integrated to give volume.

We measured breath-to-breath alveolar $\mathrm{PO}_{2}$ and $\mathrm{PCO}_{2}$ using Beckman analyzers. The $95 \%$ response times of the analyzers were 0.16 and $0.18 \mathrm{~s}$ for $\mathrm{CO}_{2}$ and $\mathrm{O}_{2}$, respectively. EEG was monitored using a single channel with an electrode placed in the right frontal position and referenced to the left mastoid. The electro-oculogram was recorded from eye electrodes referenced to the right ear. $\mathrm{O}_{2}$ saturations and ECG were used to monitor the infant's well-being but were not considered end points of this study. Sleep states were monitored according to previous criteria (3). We characterized REM and quiet sleep according to previous recommendations (12). All signals were recorded on a polygraph (model 4221, Nihon Kohden, Tokyo, Japan). A representative tracing is shown in Figure 1.

Procedure. Infants were studied on the Ohio Neonatal Intensive Care Unit (Ohio Medical Instruments, Madison, WI) in our 

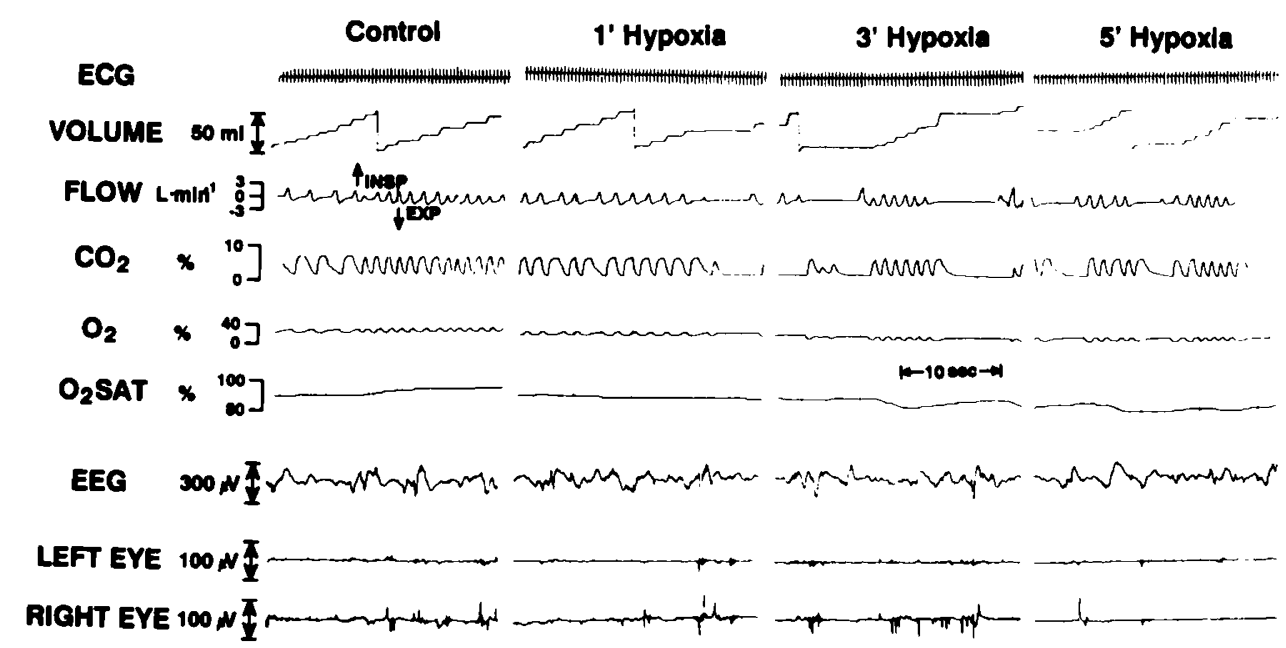

Fig. 1. Representative tracing in one preterm infant (body weight $1400 \mathrm{~g}$, gestational age $28 \mathrm{wk}$, postnatal age $17 \mathrm{~d}$ ) during REM sleep. Note the decrease in ventilation since the $1 \mathrm{st}$ min of hypoxia. This decrease was related primarily to a decrease in respiratory frequency, with breathing becoming quite periodic during hypoxia.

Table 1. Physiologic responses to inhalation of $15 \% \mathrm{O}_{2}$ in preterm infants $\leq 1500 \mathrm{~g}^{*}$

\begin{tabular}{|c|c|c|c|c|c|c|c|c|c|c|c|c|c|c|}
\hline & \multicolumn{2}{|c|}{$\begin{array}{c}\dot{V}_{\mathrm{E}} \\
\left(\mathrm{L} \cdot \mathrm{min}^{-1} \cdot \mathrm{kg}^{-1}\right)\end{array}$} & \multicolumn{2}{|c|}{$\begin{array}{c}V_{T} \\
\left(m L \cdot \mathrm{kg}^{-1}\right)\end{array}$} & \multicolumn{2}{|c|}{$\begin{array}{c}f \\
\text { (breaths. } \\
\min ^{-1} \text { ) }\end{array}$} & \multicolumn{2}{|c|}{$\begin{array}{c}V_{\mathrm{T}} / \mathrm{T}_{\mathrm{i}} \\
\left(\mathrm{mL} \cdot \mathrm{kg}^{-1} \cdot \mathrm{s}^{-1}\right)\end{array}$} & \multicolumn{2}{|c|}{$T_{i} / T_{\text {Tот }}$} & \multicolumn{2}{|c|}{$\begin{array}{l}\mathrm{P}_{\mathrm{A}} \mathrm{CO}_{2} \\
(\mathrm{kPa})\end{array}$} & \multicolumn{2}{|c|}{$\begin{array}{l}\mathrm{P}_{\mathrm{A}} \mathrm{O}_{2} \\
(\mathrm{kPa})\end{array}$} \\
\hline & Quiet & REM & Quiet & REM & Quiet & REM & Quiet & REM & Quiet & REM & Quiet & REM & Quiet & REM \\
\hline Control & $\begin{array}{r}0.173 \\
\pm 0.019\end{array}$ & $\begin{array}{r}0.186 \\
\pm 0.020\end{array}$ & $\begin{array}{r}5.2 \\
\pm 0.6\end{array}$ & $\begin{array}{r}5.0 \\
\pm 0.5\end{array}$ & $\begin{array}{r}36 \\
\pm 5\end{array}$ & $\begin{array}{r}38 \\
\pm 2\end{array}$ & $\begin{array}{r}9.0 \\
\pm 1.2\end{array}$ & $\begin{array}{r}9.0 \\
\pm 1.0\end{array}$ & $\begin{array}{r}0.354 \\
\pm 0.042\end{array}$ & $\begin{array}{r}0.350 \\
\pm 0.018\end{array}$ & $\begin{array}{r}5.28 \\
\pm 0.16\end{array}$ & $\begin{array}{r}5.20 \\
\pm 0.15\end{array}$ & $\begin{array}{r}12.49 \\
\pm 0.36\end{array}$ & $\begin{array}{r}13.29 \\
\pm 0.44\end{array}$ \\
\hline $15 \% \mathrm{O}_{2}$ & & & & & & & & & & & & & & \\
\hline $3 n_{c}$ & $\begin{array}{r}0.164 \\
\pm 0.019\end{array}$ & $\begin{array}{r}0.178 \\
\pm 0.021\end{array}$ & $\begin{array}{r}5.4 \\
\pm 0.7\end{array}$ & $\begin{array}{r}4.8 \\
\pm 0.6\end{array}$ & $\begin{array}{r}33 \\
\pm 3\end{array}$ & $\begin{array}{r}38 \\
\pm 3\end{array}$ & $\begin{array}{r}9.5 \\
\pm 1.3\end{array}$ & $\begin{array}{r}8.8 \\
\pm 1.2\end{array}$ & $\begin{array}{r}0.311 \\
\pm 0.029\end{array}$ & $\begin{array}{r}0.351 \\
\pm 0.028\end{array}$ & $\begin{array}{r}5.23 \\
\pm 0.19\end{array}$ & $\begin{array}{r}5.07 \\
\pm 0.16\end{array}$ & $\begin{aligned} & 8.29 \dagger \\
\pm & 0.37\end{aligned}$ & $\begin{array}{r}8.45 \dagger \\
\pm 0.44\end{array}$ \\
\hline $1 \mathrm{~min}$ & $\begin{array}{r}0.166 \\
\pm 0.019\end{array}$ & $\begin{aligned} & 0.171 \dagger \\
\pm & 0.017\end{aligned}$ & $\begin{array}{r}5.6 \\
\pm 0.7\end{array}$ & $\begin{array}{r}4.9 \\
\pm 0.5\end{array}$ & $\begin{array}{r}32 \\
\pm 3\end{array}$ & $\begin{array}{r}37 \\
\pm 3\end{array}$ & $\begin{array}{r}9.4 \\
\pm 1.4\end{array}$ & $\begin{array}{r}8.8 \\
\pm 1.1\end{array}$ & $\begin{array}{r}0.326 \\
\pm 0.030\end{array}$ & $\begin{array}{r}0.345 \\
\pm 0.025\end{array}$ & $\begin{array}{r}5.20 \\
\pm 0.16\end{array}$ & $\begin{array}{r}5.13 \\
\pm 0.16\end{array}$ & $\begin{aligned} & 7.91 \dagger \\
\pm & 0.44\end{aligned}$ & $\begin{array}{r}8.24 \dagger \\
\pm 0.48\end{array}$ \\
\hline $2 \mathrm{~min}$ & $\begin{array}{r}0.161 \\
\pm 0.013\end{array}$ & $\begin{array}{c}0.153 \dagger \\
\pm 0.017\end{array}$ & $\begin{aligned} & 6.1 \dagger \\
\pm & 0.8\end{aligned}$ & $\begin{array}{r}5.4 \\
\pm 0.7\end{array}$ & $\begin{array}{l}29 \dagger \\
\pm 3\end{array}$ & $\begin{array}{l}32 \dagger \\
\pm 4\end{array}$ & $\begin{array}{l}10.3 \dagger \\
\pm 1.3\end{array}$ & $\begin{array}{r}10.0 \\
\pm 1.4\end{array}$ & $\begin{aligned} & 0.293 \dagger \\
\pm & 0.035\end{aligned}$ & $\begin{aligned} & 0.289 \dagger \\
\pm & 0.035\end{aligned}$ & $\begin{array}{r}5.29 \\
\pm 0.21\end{array}$ & $\begin{array}{r}5.05 \\
\pm 0.19\end{array}$ & $\begin{aligned} & 7.32 \dagger \\
\pm & 0.48\end{aligned}$ & $\begin{aligned} & 7.21 \dagger \\
\pm & 0.49\end{aligned}$ \\
\hline $3 \mathrm{~min}$ & $\begin{array}{c}0.148 \dagger \\
\pm 0.013\end{array}$ & $\begin{array}{c}0.145 \dagger \\
\pm 0.016\end{array}$ & $\begin{array}{r}6.2 \dagger \\
\pm 0.9\end{array}$ & $\begin{array}{r}5.7 \\
\pm 0.7\end{array}$ & $\begin{array}{l}28 \dagger \\
\pm 3\end{array}$ & $\begin{array}{l}30 \dagger \\
\pm 2\end{array}$ & $\begin{array}{r}11.2 \\
\pm 2.0\end{array}$ & $\begin{array}{r}11.0 \\
\pm 1.7\end{array}$ & $\begin{array}{r}0.266 \dagger \\
\pm 0.030\end{array}$ & $\begin{aligned} & 0.268 \dagger \\
\pm & 0.022\end{aligned}$ & $\begin{array}{r}5.28 \\
\pm 0.16\end{array}$ & $\begin{array}{r}5.04 \\
\pm 0.19\end{array}$ & $\begin{aligned} & 7.23 \dagger \\
\pm & 0.51\end{aligned}$ & $\begin{array}{l}7.32 \dagger \\
\pm 0.45\end{array}$ \\
\hline $4 \mathrm{~min}$ & $\begin{aligned} & 0.146 \dagger \\
\pm & 0.017\end{aligned}$ & $\begin{array}{c}0.133 \dagger \\
\pm 0.010\end{array}$ & $\begin{aligned} & 6.1 \dagger \\
\pm & 0.7\end{aligned}$ & $\begin{array}{r}5.6 \\
\pm 0.7\end{array}$ & $\begin{array}{l}26 \dagger \\
\pm 3\end{array}$ & $\begin{array}{l}27 \dagger \\
\pm 3\end{array}$ & $\begin{array}{l}11.1 \dagger \\
\pm 1.7\end{array}$ & $\begin{array}{r}10.0 \\
\pm 1.3\end{array}$ & $\begin{array}{c}0.252 \dagger \\
\pm 0.038\end{array}$ & $\begin{array}{r}0.250 \dagger \\
\pm 0.025\end{array}$ & $\begin{array}{r}5.36 \\
\pm 0.16\end{array}$ & $\begin{array}{r}5.33 \\
\pm 0.16\end{array}$ & $\begin{aligned} & 6.49 \dagger \\
\pm & 0.63\end{aligned}$ & $\begin{array}{r}7.57 \dagger \\
\pm 0.41\end{array}$ \\
\hline $5 \mathrm{~min}$ & $\begin{aligned} & 0.146 \dagger \\
\pm & 0.012\end{aligned}$ & $\begin{array}{r}0.129 \dagger \\
\pm 0.011\end{array}$ & $\begin{aligned} & 6.1 \dagger \\
\pm & 0.8\end{aligned}$ & $\begin{array}{r}5.1 \\
\pm 0.7\end{array}$ & $\begin{array}{l}27 \dagger \\
\pm 3\end{array}$ & $\begin{array}{l}28+ \\
\pm 3\end{array}$ & $\begin{array}{l}10.2 \dagger \\
\pm 1.3\end{array}$ & $\begin{array}{r}9.2 \\
\pm 1.4\end{array}$ & $\begin{array}{r}0.267 \dagger \\
\pm 0.037\end{array}$ & $\begin{aligned} & 0.258 \dagger \\
\pm & 0.028\end{aligned}$ & $\begin{array}{r}5.44 \\
\pm 0.19\end{array}$ & $\begin{array}{r}5.25 \\
\pm 0.25\end{array}$ & $\begin{aligned} & 7.08 \dagger \\
\pm & 0.53\end{aligned}$ & $\begin{array}{r}7.24 \dagger \\
\pm 0.51\end{array}$ \\
\hline
\end{tabular}

*Values are mean $\pm S E M$. $\dot{V}_{E}$, minute ventilation; $V_{T}$, tidal volume; $f$, respiratory frequency; $V_{T} / T_{i}$, inspiratory drive; $T_{i} / T_{T O T}$, duty cycle.

$\dagger p 0.05$ in relation to control.

clinical research laboratory located adjacent to the Intermediate Care Nursery. A neutral thermal environment was maintained with skin abdominal temperature at $36.5 \pm 0.03^{\circ} \mathrm{C}(10,11)$. After appropriate placement of the various electrodes and nosepiece, we waited for the infants to fall asleep. Once they had been in quiet and REM sleep breathing $21 \% \mathrm{O}_{2}$ for $3 \mathrm{~min}$ each, $15 \% \mathrm{O}_{2}$ was given for $5 \mathrm{~min}$. A given infant had to remain in the same sleep state during the $5 \mathrm{~min}$ of inhalation of $15 \% \mathrm{O}_{2}$ to be considered for analysis. Infants tolerated the procedure well and no complications were seen in any of the infants.

Data collection and analysis. We analyzed the records by hand and transferred the data to a computer for appropriate treatment. We measured minute ventilation, respiratory frequency, tidal volume, inspiratory time, total duration of the respiratory cycle, $\mathrm{P}_{\mathrm{A}} \mathrm{O}_{2}$, and $\mathrm{P}_{\mathrm{A}} \mathrm{CO}_{2}$ for $30 \mathrm{~s}$ to $1 \mathrm{~min}$ during $21 \%$ and $15 \% \mathrm{O}_{2}$. Inspiratory drive (tidal volume/inspiratory time) and "duty cycle" (inspiratory time/total duration of respiratory cycle) were calculated.

Analysis of variance was used to test the significance of the differences between values during $15 \% \quad \mathrm{O}_{2}$ and $21 \% \quad \mathrm{O}_{2}$ and between sleep states. Values are expressed as mean \pm SEM. A $p$ value $\leq 0.05$ was considered significant.

\section{RESULTS}

Results are summarized in Table 1 and illustrated in Figures 1 and 2 . With administration of $15 \% \mathrm{O}_{2}$, there was an immediate and sustained decrease in ventilation in both sleep states, which was significant in REM sleep from the $1 \mathrm{st}$ min and in quiet sleep from the $3 \mathrm{rd} \mathrm{min}$ of breathing low $\mathrm{O}_{2}$. These changes in ventilation were primarily related to a decrease in frequency in both sleep states (Figs. 1 and 2, Table 1).

The sustained decrease in ventilation was more pronounced during REM sleep with a percentage of change in ventilation of $-33 \pm 5 \%$ compared to $-11 \pm 5 \%$ during quiet sleep at $5 \mathrm{~min}$ $(p=0.005)$. This difference between sleep states was related to a lack of increase in tidal volume in REM sleep $(-3 \pm 8 \%$ in REM versus $23 \pm 7 \%$ in quiet sleep; $p=0.02$ ) (Fig. 2, Table 1 ).

The inspiratory drive increased in quiet sleep only, paralleling the changes in tidal volume. The duty cycle decreased in both sleep states, suggesting that the changes related to hypoxia were mediated primarily through a change in timing. $\mathrm{P}_{\mathrm{A}} \mathrm{O}_{2}$ decreased similarly in both sleep states and $\mathrm{P}_{\mathrm{A}} \mathrm{CO}_{2}$ was somewhat lower in REM than in quiet sleep, although the differences were not statistically significant (Fig. 2, Table 1). 


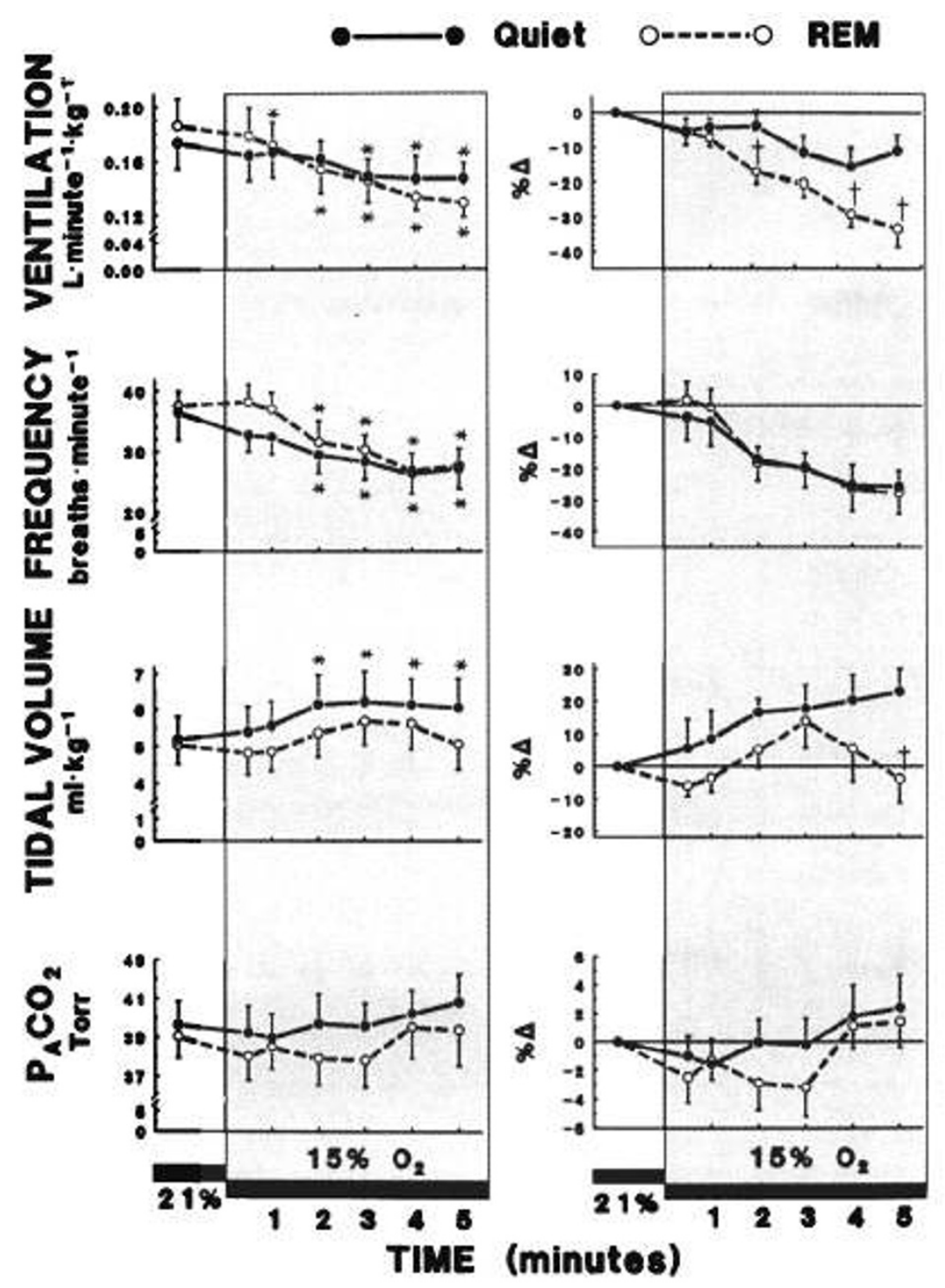

Fig. 2. Changes in ventilatory variables in response to $15 \% \mathrm{O}_{2}$. Left, Sustained decrease in ventilation occurred in both sleep states, mainly due to a decrease in frequency. Right, Percentages of change show that during REM sleep ventilation decreased significantly more than in quiet sleep as a result of a lack of increase in tidal volume. Values are mean $\pm \mathrm{SEM} ;{ }^{*}, p \leq 0.05$ compared to control; $\uparrow, p \leq 0.05$ between sleep states.

\section{DISCUSSION}

We found that the classic biphasic response to hypoxia was not observed in very small preterm infants, these infants showing only a sustained decrease in ventilation with low inhaled $\mathrm{O}_{2}$. The decrease in ventilation was primarily related to a decrease in frequency in both sleep states, usually related to the appearance of periodic breathing, and occurred despite an increase in respiratory drive (tidal volume/inspiratory time) and tidal volume during quiet sleep. This type of response is entirely compatible with the central depressive effects of hypoxia. In preterm infants, the initial inhibition of ventilation during hypoxia is mediated by a decrease in frequency rather than tidal volume $(1,2,4)$. Term infants and adult subjects change ventilation by primarily changing tidal volume. The absence of an immediate increase in ventilation in response to $15 \% \mathrm{O}_{2}$ was observed in both sleep states, although early hypoventilation (1st $\mathrm{min}$ ) was significant only in REM sleep.

The sustained decrease in ventilation in response to hypoxia has not been described previously in these infants. The mechanisms involved in this unique response are not completely clear. It is tempting to speculate that it is related to a decreased peripheral chemoreceptor response and a predominantly central depressive effect of hypoxia. The decreased response of the peripheral chemoreceptors may be explained by their already high baseline activity related to the relatively low arterial $\mathrm{PO}_{2}$ present in these infants. This would make the hypoxic stimulus unable to further increase the peripheral chemoreceptor firing, which is already very high. As a consequence, ventilation would decrease as a result of effects of hypoxia on the central chemoreceptors.

During the late response to hypoxia $(5 \mathrm{~min})$, the decrease in ventilation was observed in both sleep states, although it was significantly more pronounced in REM than in quiet sleep. This could have been explained by behavioral influences and the greater degree of hypoxemia already present at rest during REM sleep $(13,14)$. In quiet sleep, this response differed from that observed in larger preterm infants at $18 \mathrm{~d}$ of age, who present a more sustained hyperventilation (3). In REM sleep, the decrease in ventilation was about $33 \%$, slightly more pronounced than the $20 \%$ decrease observed in larger preterm infants (2-4). It is interesting that the decrease in ventilation at $5 \mathrm{~min}$ of hypoxia observed in the present study was associated with only a mild increase in $\mathrm{P}_{\mathrm{A}} \mathrm{CO}_{2}$, suggesting that some decrease in metabolism 
bringing the $\mathrm{P}_{\mathrm{A}} \mathrm{CO}_{2}$ down may also have occurred. This combined effect of central depression and decrease in metabolism has been reported previously (15).

Developmentally, this sustained decrease in ventilation mimics, although not fully, the inhibition of breathing present in the fetus $(7,8)$. In the fetus, hypoxia abruptly terminates breathing. We suspect that the degree of immaturity and the low arterial $\mathrm{PO}_{2}$ of infants $\leq 1500 \mathrm{~g}$ makes them prone to a predominant respiratory inhibition during hypoxia. Experimental evidence suggests that hypoxemia acts by an indirect suprapontine mechanism, because after electrolytic lesions in the upper lateral pons (16) or after midbrain transection at mid collicular level (17), acute hypoxemia stimulates breathing without evidence of depression. This mechanism present in the fetus could still be predominant in small and very immature infants and could be part of a complex self-protective, energy saving mechanism of adaptation to episodes of decrease oxygenation in utero. This mechanism would progressively mature with an enhanced ventilatory response to hypoxia as the fetus and the preterm infant grow.

Brady and Ceruti (1) noticed that the term infant tends to sustain hyperventilation with hypoxia after the 1st wk of life. Rigatto et al. (4) found that preterm infants are better able to sustain ventilation after $18 \mathrm{~d}$ of life. In the present study, although we did not study specifically the effect of postnatal age on the ventilatory response to hypoxia, small preterm infants were unable to sustain ventilation in the first 3 wk of life.

Our findings and those reported previously (3) suggest that the initial response to hypoxia, reflecting peripheral chemoreceptor activity, matures after $31 \mathrm{wk}$ of gestational age together with the late response in quiet sleep. In our previous study, though, the infants enrolled were older than 3 wk of age and at a later postconceptional age, possibly explaining the sustained hyperventilation in quiet sleep. The late response in REM sleep seems to be more dependent on postnatal age, although further studies are needed to define when the small preterm infant begins sustaining ventilation more efficiently in response to hypoxia. We now know that hyperventilation is not well sustained in response to hypoxia even in adult subjects, although in the adult ventilation remains above control values during late hypoxia (18).

In summary, we studied the response to $15 \% \mathrm{O}_{2}$ in small preterm infants $\leq 1500 \mathrm{~g}$. We found that these infants show only a sustained decrease in ventilation with low $\mathrm{O}_{2}$ that was primarily related to a decrease in frequency in both sleep states. An initial increase in ventilation reflecting peripheral chemoreceptor activity was never observed. We speculate that the sustained decrease in ventilation at this gestational age reflects a more pronounced inhibitory mechanism in response to hypoxia, approaching the situation in the fetus, in which low $\mathrm{O}_{2}$ abolishes breathing. Maturation of the CNS parallels the development of a mature response to hypoxia in these infants, in which susceptibility to inhibition by hypoxia disappears.

Acknowledgment. The authors thank Marie Meunier for helping with the typing and preparation of the manuscript.

\section{REFERENCES}

1. Brady JP, Ceruti EP 1966 Chemoreceptor reflexes in the newborn infant: effect of varying degrees of hypoxia on heart rate and ventilation in a warm environment. J Physiol 184:631-645

2. Cross KW, Oppe TE 1952 The effect of inhalation of high and low concentrations of oxygen on the respiration of the premature infant. J Physiol (Lond) $117: 38-55$

3. Rigatto H, Kalapesi Z, Leahy FN, Durand M, MacCallum M, Cates D 1982 Ventilatory response to $100 \%$ and $15 \% \mathrm{O}_{2}$ during wakefulness and sleep in preterm infants. Early Hum Dev 7:1-10

4. Rigatto H, Brady JP, de la Torre Verduzco R 1975 Chemoreceptor reflexes in preterm infants: $I$. The effect of gestational and postnatal age on ventilatory response to inhalation of $100 \%$ and $15 \%$ oxygen. Pediatrics $55: 604-613$

5. Sankaran K, Wiebe N, Seshia M, Boychuk R, Cates D, Rigatto H 1979 Immediate and late ventilatory response to high and low $\mathrm{O}_{2}$ in preterm infants and adult subjects. Pediatr Res 13:875-878

6. Mortola JP, Rezzonico R, Lanthier C 1989 Ventilation and oxygen consump tion during acute hypoxia in newborn mammals: a comparative analysis. Respir Physiol 78:31-43

7. Alvarez JE, Baier JR, Fajardo CA, Nowacyzk BJ, Cates DB, Rigatto H 1990 The effect of hypoxia on the continuous breathing induced by $\mathrm{O}_{2}$ or $\mathrm{O}_{2}$ plus cord occlusion in the fetal sheep. Pediatr Res 27:1748(abstr)

8. Boddy K, Dawes GS, Fischer RL, Pinter S, Robinson JS 1974 Fetal respiratory movements, electrocortical and cardiovascular responses to hypoxemia and hypercapnia in sheep. J Physiol (Lond) 243:599-618

9. Albersheim S, Boychuk R, Seshia M, Cates D, Rigatto H 1976 Effects of $\mathrm{CO}_{2}$ on immediate ventilatory response to $\mathrm{O}_{2}$ in preterm infants. J Appl Physiol 41:609-611

10. Rigatto H, Brady JP 1972 A new nosepiece for measuring ventilation in preterm infants. J Appl Physiol 32:423-424

11. Rigatto H, Brady JP 1972 Periodic breathing and apnea in preterm infants. Evidence of hypoventilation possibly due to central respiratory depression. Pediatrics 50:202-218

12. Gabriel M, Albani M, Schulte FJ 1976 Apneic spells and sleep states in preterm infants. Pediatrics 57:142-147

13. Chernick V 1978 Fetal breathing movements and the onset of breathing at birth. Clin Perinatol 5:257-268

14. Phillipson EA 1978 Control of breathing during sleep. Am Rev Respir Dis 118:909-939

15. Rigatto H, Brady JP 1972 Periodic breathing and apnea in preterm infants. Il Hypoxia as a primary event. Pediatrics 50:219-228

16. Gluckman PO. Johnston BM 1987 Lesions in the upper lateral pons abolish the hypoxic depression of breathing in unanesthetized fetal lambs in utero. Physiol (Lond) 382:373-383

17. Dawes GS, Gardner WN, Johnston BM, Walker DW 1983 Breathing in fetal lambs: the effect of brain stem section. J Physiol (Lond) 335:535-553

18. Easton PA, Slykerman L, Anthonisen NR 1986 Ventilatory response to sustained hypoxia in normal adults. J Appl Physiol 61:906-911 